\title{
The Internalization of Islamic Work Ethics in Malaysian Armed Forces Organization
}

\author{
Wan Norhasniah Wan Husin and Mazura Md Saman \\ National Defense University of Malaysia \\ Sungai Besi Camp, 57000 Kuala Lumpur, Malaysia \\ hasni_wan02@yahoo.com \\ mazurasaman74@yahoo.com mail
}

\author{
Wan Kamal Mujani \\ Department of Arabic Studies \& Islamic Civilization \\ Faculty of Islamic Studies \\ The National University of Malaysia, 43600 Bangi Malaysia \\ inawan@ukm.edu.my
}

\begin{abstract}
The objective of the study is to analyze the internalization of Islamic work ethics (IWE) in Malaysia Armed Forces organization (MAF). As the organization is one of the foundations of the nation's force based on its might in defending the society from external enemies, or internal conflicts, hence it is of utmost importance for every military personnel to be instilled with ethics and discipline. To achieve the targets, the government took the initiative to enact the Armed Forces Act 1972. To determine how far the Islamic work ethics has been embedded in the military and how it is internalized by the officers, the textual analysis method was used to meet the research objective. The findings of the study show that even though the organization tried its best to instill the IWE among the army officers, but the level of internalization was still unsatisfactory as it all depended on every officer's obligation to internalize it in their daily lives.
\end{abstract}

Keywords-Islamic work ethics; IWE; Malaysian Armed Forces; MAF; Religious Corp; KAGAT

\section{INTRODUCTION}

Work ethics is one of the major issues within an organization's management. As a comprehensive religion, Islam has outlined complete guidelines on the work ethics in an organization [1]. Based on literature, a number of researchers have debated on the concepts of IWE comprehensively. There were findings that inferred that the success of an organization depended much on the internalizing of IWE, be it at personal or organizational level. The concept of work ethics is not only debated by western intellects, but also by Muslim scholars. The importance of a systematic work procedure and cooperation between employers and employees are vital to produce high quality of work. As the internalization of work ethics that is comprehensive and effective could enhance the commitment and performance of an organization, the study will analyze the level of internalization in the MAF.

In general, the MAF is made up of three main organizations, that are the Malaysian Army (Tentera Darat Malaysia - TDM), Malaysian Royal Navy (Tentera Laut Di-Raja MalaysiaTLDM) and Malaysian Royal Air Force (TUDM). All three organizations' main role is to protect and safeguard the nation's security. However, at present, MAF is facing some problems and highlights with their officers' conduct in relation to work ethics. Among the issues are disciplinary cases, and actions that jeopardize service rules and crime [2]. The crimes committed include stealing, impersonating, falsifying documents, and smuggling drugs. All the crimes were not just committed by petty officers, but also involved ranked officers.

Hence, the study predicts that the work ethics founded upon Islamic ethics is unsatisfactorily internalized in the military organization. This is because even though the Islamic values have been nurtured in the MAF through the responsibilities of the Religious Corp (KAGAT) since 1985 [3].

\section{THE INTERNALIZATION OF ISLAMIC WORK ETHICS IN A MILITARY ORGANIZATION}

\section{A. The Scope of Islamic Work Ethics}

The term ethics is derived from the English word ethics or ethic that originates from the Greek word ethos (personality). It refers to values related to attitude displayed by an individual or a community [4]. Ethics is also defined as moral philosophies that set apart good and bad moral values. It is also referred to as the culture and norms generally accepted by the members of a community. From the Muslim perspective, it is defined as morals, which refers to actions that are accepted as norms and are not against the Islamic law.

Islam's version of work ethics aims to promote good relations among man and their Creator. The concepts and principles encompassed in IWE are based on two main sources, which are al-Quran and al-Sunnah. Meanwhile, the term morals, from the aspect of IWE refer to an entity that is present in individuals that functions in steering the person into reacting spontaneously to situations without thinking. The perfect morals will be formed through the cleansing of the heart and mind from bad deeds, and by internalizing and following all of Allah's commands [5][6]. Then, it could inculcate certain internal values in executing responsibilities whether as an employer, worker or army officer with integrity, dedication and esteem. Meanwhile, by nurturing the concept of reverence to Allah the Almighty, the internalization of Islamic work ethics can be implemented holistically.

In an organization, IWE stresses on the importance of nurturing the aspects of cooperation and collaboration when faced with problems. Apart from that, Islamic work ethics do not condone the amassing of wealth, while the welfare of workers is neglected, but advocates that employees are compensated accordingly. Meanwhile, in order to enhance work superiority and quality, Islam allows healthy competition 
to improve the performance of an organization. This is because the principles of Islamic work ethics is not to deny the needs of man, but to fulfill it with objectives of working or running a business that adheres to Islamic obligations.

\section{B. The observance of work ethics in the military organization}

Based on history, the military ethics in Malaysia was based upon the style of leadership and administration of MAF was highly influenced by the British military system [7], to the point that Islamic values that had gained foundation in the Malay Peninsula since the 7th century were sidelined [8].

However, after 40 years of inculcating of Islamic values in MAF's work ethics, it has shown some remarkable evolution, when religious activities began to be practiced individually. In fact, after the establishment of MAF, the learning and reverence of Islamic values were designated as the main agenda of the organization [9]. Through efforts of some leaders, IWE were gradually implemented in the organization especially after the establishment of KAGAT in 1985.

Continuous efforts were carried out to eliminate the culture of the British army within TDM, which included the prohibition of alcohol consumption in all MAF units from 16 September 1998, adapting the ceremony of crossing the Equator with recitation of prayers, decision to recite prayers at all official and semi-official ceremonies in MAF, and eliminating the blessing rites (Tepung tawar). The organizing of religious activities was also increased, including religious classes, weekly sermons, daily pep talks (Tazkirah), and monthly lectures at the mosque. Officers who did not know how to read the al-Quran were encouraged to attend al-Quran reading lessons with the KAGAT staff. These religious education activities not only involved MAF officers, but were extended to the family members of the officers as well, through the activities organized by the Welfare Body of the Army Officers' Wives [10].

Based upon the explanation, it shows that the organization had shown consistent efforts in reinforcing Islamic values among its officers. Even though various efforts had been implemented to instill the values of Islamic work ethics, there were still a number of army officers who were involved in criminal activities and immoral conduct, which took place during peaceful times. It showed that, the reverence of Islam was still weak at the individual level. Most of them had not succeeded in nurturing the values of Islam that resulted in misconduct. For example, in the MAF organization, even though the percentage of crime was a mere $2 \%$, but the involvement of the officers in criminal cases always received widespread coverage from the print and electronic media.

Raheman claimed that criminal cases involving MAF army officers can be classified into a few categories, that are physical crime, assets crime, morals/religious crime, drugs abuse and various crimes [11]. Based on statistics provided by researchers, the most serious crime involved drug abuse with 1,419 cases (44.14\%), followed by assets crime with 558 cases (17.36\%), physical crime with 497 cases (15.46\%), morals/ religious crime with 445 cases (13.84\%) and various crimes with 296 cases (9.21\%). Since 2005 to 2009, drug abuse cases kept increasing from year to year. As a result, research showed that the performance of the officers affected the credibility of the military organization.

\section{THE METHOD TO REINFORCE THE INTERNALIZATION OF ISLAMIC WORK ETHICS}

Referring to the above explanation, the MAF had initiated various efforts to reinforce the internalization of IWE in the organization, especially aspects involving character and personality of the officers. The first initiative was the implementation of mental and spiritual development in MAF through religious education. Through this policy, every base and team must allocate 857 hours of religious education including practical activities of Islamic rituals. The breakdown of activities included religious camps, reading of pamphlets; specific religious classes like spiritual enlighten known as Semarak Rohani and Nadwah, and Koranic reading Tilawah alQuran and others [12].

The development of spiritual enlighten was realized by internalizing the true Islamic practices, guided by KAGAT members. It includes the performing of the obligatory daily prayers, Zikir after prayers, reading of Ma'thurat, Yaasin/Tahlil, Tarawih prayers, Qiamullail, Friday prayers and others [13].

The activities mentioned above were initiatives organized by KAGAT and the team to develop the spiritual combative skill of the army officers. Combative strength refers to the 'elements related to the soul or spirit that is the core which drives the fighting and combative spirits in achieving the aims'. An excellent army officer needs total fulfillment from the aspects of physical, mental and spiritual. The physical strength will determine the mobility and quick action power when on duty. The mental strength, meanwhile, is the determining factor when faced with grave situations and managing stress. As for spiritual strength, the presence of spiritual combat power during operations and trainings will form the perfect defensive stronghold.

\section{SUMMARY}

It can be inferred that the internalization of IWE had been practiced in the military organization. However, at the individual level, the internalization was found to be unsatisfactory. As a result, there were still a number of MAF officers who were involved in disciplinary and criminal cases. Hence, in efforts to fortify MAF's reputation as the bastion of defense and sovereignty of the nation, the organization had taken several initiatives to improve religious awareness among MAF their officers.

\section{ACKNOWLEDGMENT}

This research was financially supported by Ministry of Higher Education (Malaysia) and The National University of Malaysia (Grant No. RACE-2015/2017-001).

\section{REFERENCES}

[1] Shatibi, Al-Muwafaqat, vol. 2. Egypt: Matba'ah al-Maktabah alTijariyyah, 1966. 
[2] Z. Z. Abidin, Hubungan disiplin anggota tentera darat Malaysia di Lembah Kelang dengan faktor agama (Discipline relationship between members of the Malaysian Army in the Klang Valley and religious factor), MA Thesis. Malaysia: Universiti Utara Malaysia, 2011.

[3] K. F. Azmi. Dasar Pembinaan Mental dan Kerohanian Islam (DPMKI): Masalah dan Cabaran Pelaksanaannya di Kor Agama Angkatan Tentera (KAGAT) (The Basic Construction of the Mental and Spiritual Islam (DPMKI): Issues and Challenges in it's implementation in KAGAT). Selangor: Faculty of Islamic Studies The National University of Malaysia, 2014.

[4] R.T. Garner, The Encyclopedia Americana, vol. 10. Connecticut: Grollier Incorporated, 1984.

[5] A. A. al-Maududi, Islamic Way of Life. Karachi: Islamic Research Academy, 1967.

[6] A. M. Ismail, W. K. Mujani, , W. M. H. W. Hussain \& N. I. Ya’akub, "The missing of moral entity in modern civilization: values and social aspects”, Advances in Natural and Applied Sciences, vol.6 (6), 2012, pp.985-994.

[7] W. N. Wan Husin, Peradaban Dan Perkauman Di Malaysia: Hubungan Etnik Melayu-Cina (Civilization And Racism In Malaysia: Malay Ethnic-Chinese Relations). Kuala Lumpur: Universiti Malaya, 2012.
[8] S. O. Syed Omar, Rejimen Askar Melayu Di Raja 1933-1968 (Royal Malay Regiment 1933-1968). Kuala Lumpur, Universiti Malaya, 2005.

[9] Syed Muhammad Naquib Al-Attas, Islam and Secularism. Kuala Lumpur: Angkatan Belia Islam Malaysia, 1978.

[10] M. K. Yap Abdullah and A. Mohd Islam, The Impact of Attendance in Islamic Religious Programs on Islamic Religiosity and Islamic Work Ethics: A Study On Malay Muslims Personnel in The Malaysian Army. Malaysia: n.p., 2007.

[11] Raheman @ Abd Rahman Wok, “Jenayah dalam anggota MAF (Crime in MAF's member)”, Jurnal Sorotan Darat (Journal of Land Review), vol. 28, 2008, pp. 22-26,

[12] M. M. Aini, Pentadbiran organisasi Kor Agama Angkatan Tentera (KAGAT): analisis pencapaiannya terhadap pembangunan akhlaq tentera Malaysia (Administration of KAGAT: An analysis of the development of akhlak achievement in Malaysia armies), MA Thesis. Kuala Lumpur: Academy of Islamic Studies, University of Malaya, 2004.

[13] A. M. Ismail, W. K. Mujani, , W. M. H. W. Hussain \& N. I. Ya’akub, "The missing of moral entity in modern civilization: values and social aspects”, Advances in Natural and Applied Sciences, vol.6 (6), 2012, pp. 985-994. 